\title{
Teaching online enantiosemia and word diffusion aspects during the coronavirus pandemics
}

\author{
Aisulu Nurtayeva - Gulmira Abdirassilova - Makbal Karbozova - Eker Suer \\ - Sandugash Rakhimzhanova
}

DOI: 10.18355/XL.2021.14.01.21

\begin{abstract}
The article's primary goal is to demonstrate in the online teaching of language the philological aspects of the system and patterns of the occurrence of enantiosemia in the language to students. The article shows how language theoretical aspects can be taught in online learning. It also gives definitions of enantiosemic words for this purpose: to study their origin in the language system; to analyze the position in the text due to a change in syntactic meaning; tasks such as determining the nature of word formation, the study of the lexical stability. Enantiosemia occurs mainly in the form of interstitial diffusion. We use words in the form of opposite meanings during the speech, which are then stabilized and translated into a symmetrical second meaning. The study considers the secondary meaning transition through semantic analysis, contrasting, oppositional, and component analysis. We support the idea of developing the meanings of words being determined by the method of cognitive analysis. Thus, when instructing students to study the nature of enantiosis that acquire a new meaning that can be both stable or unstable in the language, it is necessary to do it in a context-sensitive manner and supplement the vocabulary.
\end{abstract}

Key words: teaching, enantiosemia, phrase, functional use, online learning, coronavirus nominative enantiosemia

\section{Introduction}

In the field of education, an emergency transfer of the educational process to a distance form using e-learning technologies was chosen as an appropriate measure. In principle, such a setting corresponds with the current level of digital-technologiesavailability for the majority of the country population. Besides, according to official accreditation requirements, the vast majority of educational institutions are required to have an Internet connection, which is an essential criterion for assessing the school ability to work remotely using digital technologies.

As the global world became influenced by the great coronavirus pandemics, the institutions faced a problem with the present form of education. The new situation forced schools to switch to online education. In this respect, it is better to mention that humanities disciplines are not easy to teach even though students can study some theoretical aspects during the self-preparation time on their own. In principle, in academic subjects that predominantly provide lectures and/or independent mastering of the material, it is easier to transition to online training quickly. Courses with digitized learning content, especially if it clearly conforms to school official curriculum, have advantages in transitioning to online learning in the short term versus non-digital subjects content.

Online teaching is very different from face-to-face teaching. The learning content and students are the same, but one needs a different set of skills for teaching exclusively online. Even for teachers with extensive experience in using educational technologies while teaching students in the classroom, whose students regularly use educational technology for extracurricular activities, it can be challenging to work exclusively in the online environment. Pedagogical methods focused primarily on a teacher's oral presentation while lecturing or on students to independently fulfill teacher's tasks

XLinguae, Volume 14 Issue 1, January 2021, ISSN 1337-8384, eISSN 2453-711X 
while using teaching materials might be easily transferred to the online educational environment (Novacikova, 2017). But it cannot be said about more complex teaching methods, for example, used where learners participate in a student-centered or projectbased approach. Thus, this research paper will demonstrate different techniques in teaching online enantiosemia and word diffusion aspects to the language students during the coronavirus.

One of the mysterious, ambivalent linguistic units of our language is enantiosemia the object of the study of lexicology. The lack of connection between content and form has led to the ambiguity of many linguistic units. Linguistic symbols can have multiple meanings. However, the same content can be used differently in different contexts. "There are no logical restrictions on the words used by the speaker in the subtext. In most cases, the speaker does not use the words literally, but in the opposite sense, that is, ironically. The enantiosemia of linguistic units may violate linguistic symbols' laws since the laws of linguistic types cannot exist without each other in content and form. The occurrence of the phenomenon of enantiosemia is influenced by linguistic and extralinguistic factors that directly reflect the facts of objective reality" (Scherzo,1983, p 348). Enantiosemia is a serious and significant problem not only in the Kazakh language but also in general linguistics, including Turkology. As for the study of history, the first Russian researcher, V.I. Scherzo, pays special attention to the history of its origin, dialectal features, and semantic development (Scherzo,1983).

According to researcher D. Osmonalieva, the phenomenon of enantiosemia in the Kyrgyz language started to be studied in the 1980s (Osmonalieva, 1976). In research, the Kyrgyz scientist B. Usubaliev considered enantiosemia a particular type of antonyms and gave some information about its nature, origin, and variations (Usubaliev, 1998).

In some general linguistics, the phenomenon of enantiosemia is usually combined with such categories as synonymy, antonymy, polysemy, and homonymy. A considerable number of dissertations in Russian linguistics also examined the phenomenon of enantiosemia. In particular, A. Nechyaeva (2008), T. Ganeev (2003), A. Yakunchenkova ( 2007), L. R. Makhmutova (2009), and in others works. The phenomenon of enantiosemia in Kazakh linguistics was not the subject of special studies, except for some textbooks on lexicology and dictionaries of linguistics. Nurberdiev (2008), Shoibekova (2018) do not have many serious works, except for some studies and articles. The antonyms researcher, J. Musin, explains in his research entitled Antonyms in the Kazakh language: "In our language, we sometimes use antonyms in the opposite sense from their main meaning ... This is usually done as a result of ridiculing something and is an indispensable tool for irony" (Shoibekova, 2018, p 190). Although we can say that such a phenomenon occurs in language, we should not name it enantiosemia.

Scholars researching the phenomenon of enantiosemia suggest its association with the same, ambiguous words and lexical-semantic units. However, different names of terms given to these words indicate the diversity of their vocabulary. In the dictionary of linguistic terms, the meaning of the word "enantiosemia" defines the term as originating from the Greek language: Enantios - contradictory, opposite + sema - sign. The development of antonyms may be observed in the polarization of meanings. For example, the term "probably," meant "probably" in the past. The modern meaning is much closer to "likely, apparently." In the word "honor," the old meaning is "show honor, show respect." The modern meaning is "curse, bear" (Makhmutova, 2009).

O. S. Akhmanova defines enantiosemia as a "polarization of values." (Akhmanova, 1960) As mentioned above, enantiosemia is featured in lexicology textbooks only through oral interpretation. For example, Y. D. Apresyan recognizes enantiosemia as the difference between homonyms according to words among the enantionyms of the same name, there is ambiguity (Apresyan, 1995). In our understanding, the nature of 
ambiguous words is different from the nature of opposing terms. Ambiguous terms or phrases are declared similar concepts, and enantiosemic terms are designated conflicting concepts. As a rule, words with opposite meanings are called homonyms, and by definition, these are words that have the same appearance, are read the same, pronounced the same, but have two different meanings. In this sense, there is no similarity between homonyms and enantiosemia. Since homonyms are the terms of two different concepts, both fully formed names and enantiosemic words will result from words formed by lexical-semantic word-formation methods. There is no similarity between homonyms and enantionyms. The reasons for the appearance for both are different. For example, when using enantionims in discourse as the only distinguishing feature of enantionims, in addition to the meaning in context, the original meaning comes to mind. Simultaneously, ridicule and mockery of the speaker change the meaning of the word, and the second contradictory meaning is not in homonym, but only in enantionims. These signs describe the characteristics of homonyms and enantionims. The Arab scholar, D. Muhammad al-Munajid, disagrees. According to him, "enantionims is a type of homonym" (Nurberdiev, 2007). Of course, our answer to this question is that there are only personal similarities with the words of the same name, but it seems that they do not consider the fact that enantionims have a semantic connection. When the meaning of the enantionim stabilizes, a new name forms in the language. And if it does not stabilize, we recognize it as a cross-style distribution or syntactic meaning within the text's context. The values of stabilizers are language users. The more users apply the language, the more the language unit stabilizes. F. S. Batsevich considers enantiosemia to have the characteristic of colloquial speech (Batsevich, 1987). The opinion of F. S. Batsevich also supports our view that the above text will have a new meaning. Thus it means that in the first place, the meaning occurs as a result of thinking, imagery, which automatically appears when speaking.

The textbook of Sagyndykuly B., Modern Kazakh language (lexicology), says: "The use of one word in two opposite senses is called the phenomenon of enantiosemia" (Klegr, 2013). Also, a Kazakh researcher M. Nurberdiev considered the question of translating words from Arabic to Kazakh and their enantiosemia (Batsevich, 1987). By analyzing these definitions, we attribute enantiosemia to the fact that any term has two or more opposite meanings. There is also a semantic connection between words recognized by enantiosemia. In particular, words with external morphemes are used in the same but opposite sense.

We consider it only in terms of the transformation of lexical meaning into an emotionally-expressive enantiosemia. In general, the range of lexical meanings is much more comprehensive. Besides, in Kazakh linguistics, words with emotional, expressive, and evaluative meaning should be considered separately. However, in our linguistics, it is more common to define emotional-expressive words by a double term. Emotional evaluative vocabulary splits into two groups: 1) terms of gratitude, 2) terms of protest. The first group has a positive value, and the second has a negative value. Here, the macrosema of emotional-evaluative words answers the question of what specific emotions and feelings affect the emergence of gratitude and dissatisfaction. The semantics of emotional verbs that have an evaluative value are love, affection, supplication, support, encouragement, pampering, satisfaction, amazement, fear, remorse, dissatisfaction, condolence, consolation, pity, sympathy, opposition, disapproval, ridicule. We can divide them into specific groups, such as teasing, humiliation, mourning, dreaming, mocking, anger, hatred. These semantics are very capable of generating enantionims. Because the resentment is real, the meaning of ridicule and mockery has a negative emotional effect. Secondly, most words that express an emotional value have an enantiosemic property. Take, for example, the term "baigus": Baigus was in so much discomfort that he looked at him

XLinguae, Volume 14 Issue 1, January 2021, ISSN 1337-8384, eISSN 2453-711X 
sympathetically // Baigus, in the context of recognizing the meaning of the phrase that he must have been exasperated, sighed, mocked, caressed, disliked, etc. We can acknowledge that it makes sense. Also, there is a considerable amount of tools to determine their meaning and limit them. For example, there are cases when the meaning of the word is not a single sentence, but in some cases, it can be a whole work of art.

In collecting linguistic data related to emotional-expressive enantiosemia, in our opinion, it is necessary to pay attention to the following two issues. 1) to reveal the causes of the emergence and development of emotional-expressive enantiosemia, and 2) divide them into mutually semantic groups. There is a close connection between these two issues. Because, first of all, there is a difference in the formation of emotional-expressive enantiosemia. And this question is in the first place in determining which of them belongs to the semantic group. Secondly, it is challenging to classify various types of enantiosemia into a semantic group because most of them are ambiguous and variable.

Each word in our language can have different meanings, but not all of them belong to the same enantiosemia. The active and competitive use of positive and negative meanings and such opposite meanings have become a constant perception among them.

Although many scientists ascertained the methods and techniques that can strengthen foreign language education, we have to admit that today there is still a lack of specialists with a high level of foreign language and knowledge of their profession. To have such specialists, the teachers also must be very competent and versatile. They also need to have in-depth knowledge and experience in the field of language and subject matter. Thus, we attempted to reconsider methodic guidelines that can complement and improve the Natural-studies students' competence by observing the educational process and applying the existing methods and approaches. The most effective technique to develop students' professional orientation and foreign language acquisition and study any topic during online lessons is the methodology with a precise application of a case study. It is not new, but we've tried to transform some changes into instructions, organization, and the use of the case-study-techniques during the teaching.

Several scientists such as Kunakova K.U., Zhumabekova G.B., Uzakbayeva S.A., Raimbekova G.S., Sadykova A.A., Adyrbekov D.T., Parmanova A.B., Ariyan M.A. conducted research concerning case-study-techniques. As it is known, the case-studytechnique is used widely to prepare students at universities and high schools worldwide. This methodology allows them to develop a whole range of essential skills and abilities (analytical, practical, creative, communicative, introspective, and reflective), as well as personality traits such as communicative competence, social responsibility, the desire for knowledge, and self-improvement. (Gadusova, Haskova, Szarsoi, 2020). The report "Recommendations for Using the Case Study Method in International Research" also notes its great potential in the educational process (Usubaliev, 1998). It indicates helping to reveal and establish relationships between objects, teaches to understand the causes of events, presents a description of the existing production problem situation in a "live" exciting language, which leads to a deeper understanding of this situation.

According to researchers, the case-study-technique also helps to solve the main tasks of professional foreign language education: familiarizing students with the conditions of practical production activities; training professionals oriented towards success; encouraging analytical and critical thinking; familiarization of students with the functional activities of enterprises; students gaining practical skills and developing leadership and communication skills; building up and activating human, intellectual and social capital; the formation of a system of professional, universal, moral, cultural and other values (Nechaeva, 2008). 


\section{Methods}

This study was designed to analyze philology faculty students' attitudes to professional foreign language education and the usage of the case technology in the lessons. During the study, a mixed approach was used with the help of interviews and observations. Twenty-two philology students were interviewed to collect the data. The interview aimed to identify the students' attitude to the foreign language and the use of communicative-cognitive cases in the educational process. Additionally, the results of the study considered the online class observation.

\section{Results}

Students were interviewed during their study. They answered the questions in table 1, which analyzed their attitude to foreign language education and the techniques used during the class:

Table 1 - Interview questions with students' answers

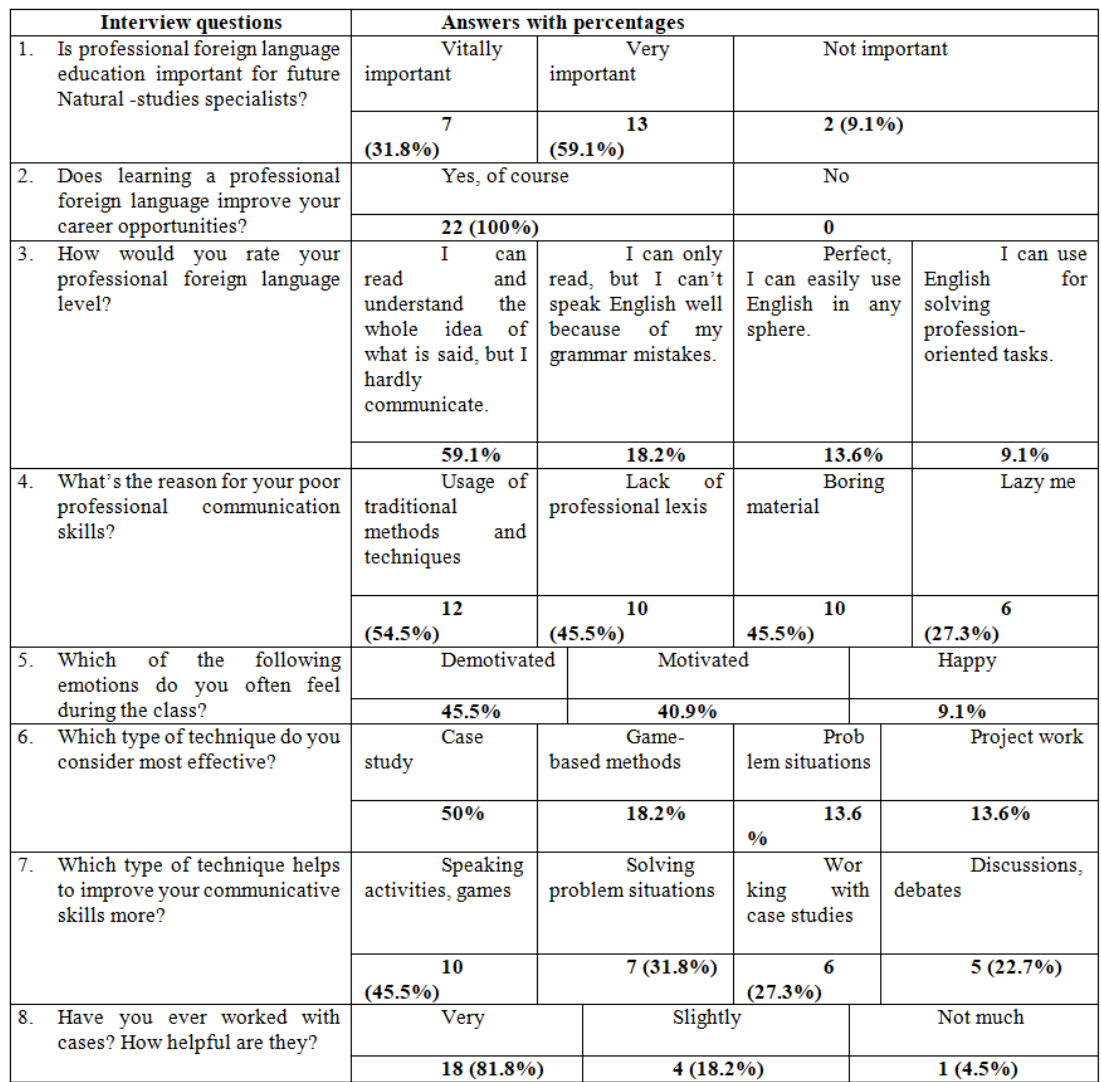

Overall, 22 students from the $2^{\text {nd }}$ year of study took part in this interview. According to the results, about $60 \%$ of the students admit that professional foreign language education is essential for their future profession. They are all very confident that a professional foreign language will improve their career opportunities. However, 13 $(59,1 \%)$ students out of 22 have trouble speaking a foreign language even if they can read and understand the speech. The main reason for this was the usage of the

XLinguae, Volume 14 Issue 1, January 2021, ISSN 1337-8384, eISSN 2453-711X 
traditional methods and techniques $(54,5 \%)$, then the boring material that is presented by the teacher (45.5\%), and students' lack of professional lexis $(45.5 \%)$.

Consequently, $45.5 \%$ of the students felt demotivated during the lesson, whereas $40.9 \%$ felt motivated, and others felt happy. When students were prompted to identify the most effective type of technique, $50 \%$ chose the case-study-technique, while $18.2 \%$ preferred using a game-based method. Others mentioned problem-solving situations and project methods.

Surprisingly, ten students said that speaking activities and games mostly improve their professional communication skills. Seven students chose problem-solving situations, and six students decided to work with case studies. Finally, for the question to what extent cases are helpful, 18 students, that is $81.8 \%$, answered positively about this technique. The whole results of the interview are presented in the following diagrams

\section{Diagram 1}

How would you rate your professional foreign language level?

22 responses

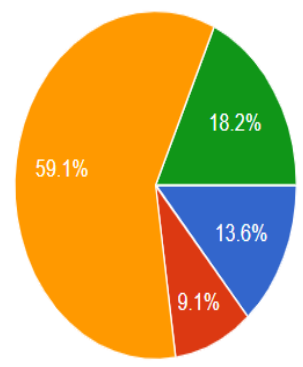

Perfect, I can easily use English in any sphere

I can use English for solving professionoriented tasks

I can read and understand the whole idea of what is said, but I hardly communicate

I can only read, but I can't speak English well because of my grammar mistakes

I can't speak English at all

\section{Diagram 2}

Does learning professional foreign language improve your career opportunities?

$0 / 22$ correct responses

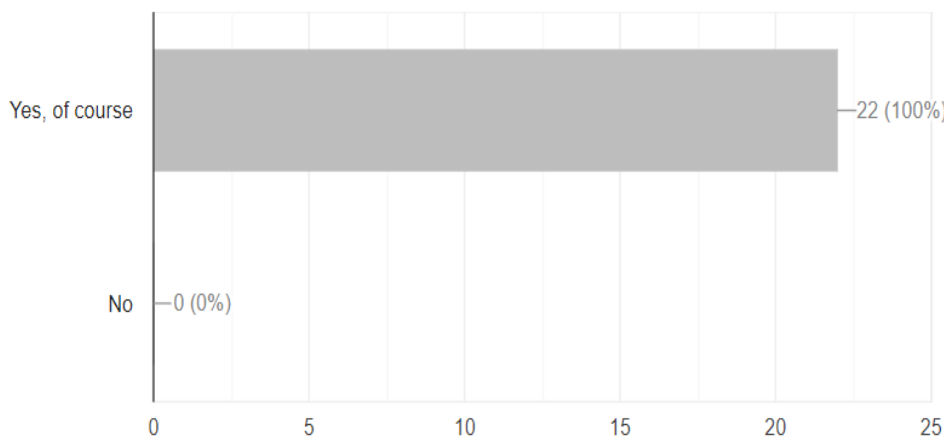




\section{Discussion}

Based on the interview survey results, it is clear that studying this topic has become vitally important for students these days. Over the past couple of decades, most universities have been paying particular attention to acquiring a foreign language regardless of their specialty because of the radical changes in social development and political conditions in our society. Therefore, these circumstances have led universities to prepare specialists to foster international relations and establish contacts with representatives of different nationalities in the economic, social, and political spheres at different levels. (Alexy, Ambrozy, Lokajicek, 2017).

We found out that case studies are used most successfully only in combination with other methods of teaching foreign languages. Therefore, in our algorithm of work, we use the method of keywords, communicative clusters, and role play. The method of keywords is beneficial in learning and using new terminology. Thanks to this method, students get to know and understand their profession's terminology and concepts more effectively and efficiently. Students will mainly be more concentrated on the case itself, not on their speech and using these words while resolving case situations. Communicative clusters allow the learners to systematically prepare the speech to form various types of sentences and develop the ability to present their work in a foreign language publicly. Naturally, working with the communicative-cognitive cases proved to be very useful and engaging for students. On the other hand, the teachers also must keep in mind that presenting the teaching material should be engaging and motivating. (Kwiecien-Niedziela, Polok, Mala, 2020). The cases must be comprehensive, holistic and functional, multilevel and multilateral, and should meet modern life requirements. The teachers can also use other additional materials as graphs, charts, diagrams, information of an economic, social, and historical nature according to the theme to diversify the teaching process. (Bianco, Cobo, 2019)

So, case studies spark lively classroom discussions and provide real-world management lessons that students can put into practice in their professional lives. In other words, students discuss real-world business situations in an artificially created professional environment. Many students are more inductive than deductive reasoners, which means that they learn better from examples than logical development, starting with basic principles. The use of case studies can therefore be a very effective classroom technique (Nurberdiev, 2008).

This technique also allows teachers to solve several problems simultaneously. Most importantly, it enables students to learn the course material more efficiently by including the motivational sphere of the student into the educational process. It also develops creative abilities, the capacity for further self-development and selfeducation, communicative skills, establishes emotional contacts among students; implement educational objectives. It allows students to work in a team and listen to their group mates. The case-study technique in developing professional communicative competence relieves students' nervous tension. It gives the possibility to change the form of their activities, to focus their attention on the key issues (Musin, 1984).

\section{Conclusion}

In this research study, we have analyzed the necessity of foreign language competence of philology students and the techniques that help to achieve it. It became apparent that the online teaching of enantiosemia and word diffusion aspects to the language students during coronavirus pandemic are essential for this specialization in the modern world. (Murgas, Petrovic, 2020). We managed to identify the students' attitudes towards case-study techniques during our research with the help of the interviews. This specific technique was supported to be used in the class by the majority of students. It is important to notice once again that the case study technique

XLinguae, Volume 14 Issue 1, January 2021, ISSN 1337-8384, eISSN 2453-711X 
provides students with an excellent opportunity to apply creatively the learned language material based on their professional knowledge and allows students to adapt to real-world situations. As an interactive teaching tool, it wins a positive attitude from students who see it as an opportunity to take the initiative, to feel independent in mastering theoretical knowledge and mastering practical skills. That is why we consider case-studies as a useful technique for the active training of philology students based on real professional situations. For further research, we would like to analyze supplementary techniques that are used together with the case-study technique (Khonamri, Ahmadi, 2015). In addition to this, we will attempt to present and evaluate examples of the cognitive-communicative cases. Our final remarks conclude that students understood enantiosemia as the opposite within one word and the use of one word in the opposite meaning. Enantiosemia results from the opposite meaning of a word. To identify whether enantiosemia occurs in the lexical system and is a linguistic phenomenon, it is necessary to compare it with other linguistic phenomena. The commonality and similarity of antonyms and enantiosemia lie in the fact that they are used in opposite senses. Enantiosemia and antonymy differ in the organization of opposing meanings, ways, means of realization, level of recognition, relevance to the context, and objective reality.

Enantiosemia can be considered not only as an antonym but also as a different form of polysemy. The reason is a $\neg$ semantic core that unites enantiosemia and polysemy. However, the relationships between the meanings of polysemous words do not coincide. There lies the difference between the variety of communication features. In polysemy, combined meanings have different sense, while enantiosemia are used in an opposite sense.

\section{Bibliographic references}

ALEXY, J. - AMBROZY, M. - LOKAJICEK, M. V. 2017. Precision and causality in economics. In: Economic Annals XXI, vol. 163, n. 1-2, pp. 4-9. ISSN 1728-6220.

APRESYAN YU. D. 1995. Selected works. T 1. Lexical semantics. / Yu. D. Apresyan. 2nd ed. pererab and add. In: School "Languages of Russian culture", publishing company "Eastern literature" of the Russian Academy of Sciences, $472 \mathrm{p}$.

AKHMANOVA O.S. - BELCHIKOV YU.A. - VESELITSKY V.V. 1960. On the question of the "correctness" of speech, Questions of linguistics. vol. 2.

BATSEVICH F. S. 1987. On verbs with opposite meaning, Rus. language at school. n. 4. pp. 86-90.

BIANCO, R. - COBO, M. O. 2019. The linguistic integration of refugees in Italy. In: Social Sciences, vol. 8, n. 10, 284 p. ISSN 2076-076.

EXPLANATORY DICTIONARY OF THE KAZAKH LANGUAGE: 10 VOLUMES. 1976. Almaty: Science, 695 p.

EXPLANATORY DICTIONARY OF THE KAZAKH LANGUAGE: 10 VOLUMES. 1979. Almaty: Science, 510 p.

EXPLANATORY DICTIONARY OF THE KAZAKH LANGUAGE. 2008. headed by T. Zhanuzakov. Almaty, In: Dyke Press, 968 p.

GADUSOVA, Z. - HASKOVA, A. - SZARSOI, D. 2020. Teachers' competencies evaluation: Case study. In: Science for Education Today, vol. 10, 3, pp. 164-177. ISSN 2658-6762.

GANEEV B. T. 2003. Primary enantiosemia and diffusion in the language/ / Bulletin of the Orenburg State University, n. 4, pp. 9-14.

GAVRILENKO, N.N. - BIRYUKOVA, YU.N. 2019. Forecasting the translation profession development: Foresight Technology. Journal of history culture and art research. vol. 8, n. 4, pp. 123-134. doi: 10.7596/taksad.v8i4.2365

GUZHELYA, D. - KURILENKO, V. - BIRYUKOVA, YU. 2020. The specifics of distance methodological support for foreign language teachers in a foreign language 
environment. Revista Inclusiones, vol 7. pp. 22-31 Available online: http://revistainclusiones.org/index.php/inclu/article/view/1312

KHONAMRI, F. - AHMADI, F. 2015. The effect of metacognitive strategy training and raising EFL learners' metacognitive awareness on listening comprehension. In: Indonesian Journal of Applied Linguistics, vol, 5, n. 1, pp. 19-28. ISSN 2301-9468. KLEGR, A. 2013. The limits of polysemy: Enantiosemy. vol. 23, pp. 7-23. Available online:

https://www.researchgate.net/publication/292484494_The_limits_of_polysemy_Enant iosemy/citation/

KWIECEN-NIEDZIELA, E. - POLOK, K. - MALA, E. 2020. Drama techniques as correlators of the level of english language speaking anxiety. In: Integration of Education, vol. 24, n. 1, pp. 98-110.

MAKHMUTOVA L. R. 2009. Place of enantiosemia in the language system L. R. Makhmutova In: Scientific notes of Kazan State University. Human Sciences series. Kazan, vol. 151, n. 3, pp. 276-281.

MURGAS, F. - PETROVIC, F. 2020. Quality of life and quality of environment in Czechia in the period of the COVID-19 pandemic. In: Geograficky casopis, vol. 72 n.2, pp. 261-274. ISSN 0016-7193.

MUNKOVA, D. - HODAKOVA, S. - WELNITZOVA, K. 2014. Causal uncertainty and translation. In: Studia Psychologica, vol. 56, n. 3, pp. 221-232. ISBN 0039-3320.

NOVACIKOVA, D. 2017. Environmental issues and reflection of their perception in internet media. In: Communications - Scientific Letters of the University of Zilina, vol. 19, n. 1, pp. 30-34. ISSN 1335-4205.

MUSIN, J. 1984. Dictionary of antonyms of the Kazakh language. Almaty: School, $176 \mathrm{p}$.

NECHAEVA, A. 2008. "Popular linguistics: enantiosemia", Available online: https://newslab.ru/article/576649

NURBERDIEV, M. 2008. The phenomenon of enantiosemia in the Kazakh language, In: Bulletin of KazNU, series of philological Sciences, vol. 3, n. 25, pp. 67-70

NURBERDIEV, M. 2007-2008. On some enantiosemic names in the Arabic language In: Collection of problems of Islamic studies and Arabic philology. Proceedings of the International scientific-practical conference. $113 \mathrm{p}$.

OSMONALIEVA, D. 2007. Enantiosemia in the Kyrgyz language. 10.02.01 - Kyrgyz language. Author's abstract. Thesis for the degree of Candidate of Philological Sciences. Bishkek,

PISANSKI, K. - KOBYLAREK, A. - JAKUBOWSKA, L. - NOWAK, J. WALTER, A. - BLASZCZYNSKI, K. - KASPRZYK, M. - LYSENKO, K. SUKIENNIK, I. - PIATEK, K. 2018. Multimodal stress detection: Testing for covariation in vocal, hormonal and physiological responses to Trier Social Stress Test. In: Hormones and behavior, vol. 106, pp. 52-61. ISSN 0018-506X

SCHERZO, V. I. 1983. About words with opposite meanings (or about the so-called enantiosemia) In: Philosophical notes. Voronezh, vol. V-VI.

SHOIBEKOVA. G.B. etc. 2018. The phenomenon of enantiosemia in linguistics In: Science and life of Kazakhstan, n. 58. - pp. 65-68

"Shyldem, shyldem, shylde aium..." July, 2016 Available online: http://anatili.kazgazeta.kz/p=38095

SOROKOWSKI, P. - GROYECKA, A. - BLASZCZYNSKI, K. - FRACKOWIAK, T. - KOBYLAREK, A. 2019. Registered reports as a method to increase credibility of science - Experimental study among psychology students. In: Journal of education, culture and society, vol. 10, N. 2, pp. 67-75. ISSN 2081-1640

USUBALIEV, B. 1998. Dictionary of antonyms of the Kyrgyz language. Bishkek YAKUNCHENKOVA. A. 2007. On the problem of the status of enantiosemia in the lexical-semantic system of legal terminology from the point of view of diachrony.

XLinguae, Volume 14 Issue 1, January 2021, ISSN 1337-8384, eISSN 2453-711X 
Available online: http://cyberleninka.ru/article/n/k-probleme-statusa-enantiosemii-vleksiko-semanticheskoy-sisteme-yuridicheskoy-terminologii-s-tochki-zreniyadiahronii\#ixzz3Sk4Cq8wy

Words: 4372

Characters: 30022 (17,70 standard pages)

Nurtayeva Aisulu

acting. Prof. Abdirassilova Gulmira

Karbozova Makbal

Rakhimzhanova Sandugash

Kazakh National Women's Teacher Training University

99 str. Aiteke Bi, Almaty

050000, Almaty

Kazakhstan

Prof. Süer Eker

University of Bashkent

20, Blv, Campus Baglika

06810 Ankara

Turkey

perzhanzhan@mail.ru 